\title{
METAFORA SEBAGAI KEKUATAN RETORIK DALAM EDITORIAL MEDIA MASSA
}

\section{METAPHORS AS RHETORICAL POWER IN MASS MEDIA EDITORIAL}

\author{
Mulharnetti Syas ${ }^{1}$, Udi Rusadi ${ }^{2}$ \\ ${ }^{1}$ Program Studi Ilmu Komunikasi, Institut Ilmu Sosial dan Ilmu Politik Jakarta, \\ Jl. Raya Lenteng Agung No.32 Jakarta Selatan 12610, Indonesia \\ ${ }^{2}$ Program Pascasarjana, Institut Ilmu Sosial dan Ilmu Politik Jakarta, \\ Jl. Raya Lenteng Agung No.32 Jakarta Selatan 12610, Indonesia \\ 1'mulharnetti.syas@iisip.ac.id; ${ }^{2}$ udi.rusadi@iisip.ac.id \\ Diterima tgl. 01/02/2021 Direvisi tgl. 12/05/2021 Disetujui tgl. 12/05/2021
}

\begin{abstract}
Editorial as a space of opinion for the media trying to influence its readers both through the structure of editorial anatomy and the use of language. One aspect of language is the use of metaphors. This article reports the research results about how the rhetorical power of metaphors in the structure of editorial anatomy. The concepts and theories used are about metaphors as thoughts, editorial structures, and persuasive acts of rhetoric, namely: logos, ethos, and pathos. The method used to find the rhetorical meaning of the metaphor is the Metaphor Identification Procedure (MIP) that was presented by the Pragglejaz. The editorial studied is the editorial of the Republika Newspaper and Media Indonesia Newspaper. The results of the study showed that there are two major issues, namely the issue of a new cabinet and the issue of corruption. Metaphors are used in the anatomy of editorial attention, conviction, and direction, but they are not comprehensive. Metaphors become rhetorical powers as part of logos and phatos. The metaphors used in the new cabinet issue give warnings and demands to the elected president about the cabinet being drafted. The metaphors used in the issue of corruption build a picture and thought that the existing parliament does not have legitimacy as people's representatives. Theoretically, this research finds double metaphorical rhetoric with an editorial anatomical structure that reinforces the persuasive dimensions of rhetoric on the elements of logos and phatos.
\end{abstract}

Keywords: Editorial, Media, Metaphor, Rhetoric, Structure

\begin{abstract}
ABSTRAK
Editorial sebagai ruang opini bagi media berusaha untuk memengaruhi pembacanya, baik melalui struktur anatomi editorial maupun penggunaan bahasa. Salah satu aspek bahasa adalah penggunaan metafora. Artikel ini melaporkan hasil penelitian tentang bagaimana kekuatan retorik metafora dalam struktur anatomi editorial. Konsep dan teori yang digunakan ialah tentang metafora sebagai pemikiran, struktur editorial, dan tindakan persuasif retorika, yaitu logos, ethos, dan pathos. Metode yang digunakan untuk menemukan makna retorik metafora ialah Metaphor Identification Procedure (MIP) yang dikemukakan Pragglejaz Group. Editorial yang diteliti adalah editorial surat kabar Republika dan Media Indonesia. Hasil penelitian menunjukkan bahwa terdapat dua isu besar yang menggunakan metafora, yaitu isu kabinet baru dan isu korupsi. Metafora digunakan pada anatomi editorial attention, conviction, dan direction, tetapi tidak menyeluruh. Metafora menjadi kekuatan retorik sebagai bagian dari logos dan phatos. Metafora yang digunakan dalam isu kabinet baru memberikan peringatan dan tuntutan pada presiden terpilih tentang kabinet yang disusun. Metafora yang digunakan dalam isu korupsi membangun gambaran dan pemikiran bahwa parlemen yang ada tidak memiliki legitimasi sebagai wakil rakyat. Secara teoritis, penelitian ini menemukan retorika ganda (double retoric) metafora dengan struktur anatomi editorial yang memperkuat dimensi persuasif retorika pada unsur logos dan phatos.
\end{abstract}

Kata Kunci: Editorial, Media, Metafora; Retorika, Struktur

\section{PENDAHULUAN}

Dalam praktik jurnalistik, media memproduksi berita dengan melaporkan fakta-fakta tentang berbagai peristiwa dan pendapat yang terkait pada suatu isu tertentu. Ketika memproduksi dan mendistribusikan berita, para wartawan haruslah memahami berbagai kriteria atau syarat sebuah 
berita, yaitu memenuhi kepentingan publik, faktual, aktual, berimbang (McQuail, 2010). Dalam berita yang disajikan media massa, tidak boleh bercampur antara fakta dengan pendapat wartawan, baik secara perorangan maupun sebagai lembaga.

Jika wartawan atau redaksi ingin mengemukakan pendapatnya, misalnya pendapat tentang berbagai isu yang berkembang dalam pemberitaan, mereka dapat menyusun dan menyajikannya dalam bentuk editorial media, pojok, dan kolom. Jenis karya jurnalistik yang termasuk kategori opini tersebut, sengaja ditulis oleh wartawan agar pendapat dan sikap mereka terhadap suatu permasalahan dapat diketahui masyarakat. Jika kita cermati, opini yang ditulis wartawan dalam bentuk artikel, feature, dan kolom dicantumkan nama penulisnya. Sedangkan dalam editorial tidak dicantumkan nama penulisnya karena editorial ditulis atas nama redaksi, bukan individu.

Media secara fungsional tidak saja melakukan produksi dan distribusi informasi tentang berbagai fakta dan peristiwa yang terjadi di berbagai belahan dunia, tetapi juga mengembangkan opini yang diharapkan bisa mencerahkan kehidupan masyarakat. Dalam posisi ini, untuk menghadapi berbagai situasi di tengah masyarakat, media memiliki positioning ideologis yang akan mengonstruksi berita tersebut. Selain itu, media juga berusaha melakukan persuasi untuk memperjuangkan posisi ideologisnya. Menurut Van Dijk (1980), editorial merupakan gabungan wacana media dan wacana pendapat dengan menggunakan bahasa yang memiliki kode-kode ideologis.

Editorial sebagai wacana media dan wacana pendapat melakukan berbagai upaya untuk memengaruhi khalayaknya. Misalnya, dengan menggunakan metafora untuk menjelaskan posisi ideologis media berkaitan dengan isu yang dibahas dalam editorial. Studi tentang penggunaan metafora telah banyak dilakukan. Refaie (2001) meneliti penggunaan metafora tentang laporan pencari kerja orang-orang Kurdi di Italia. Temuan penelitian tersebut menggambarkan bahwa metafora yang digunakan untuk laporan pencari kerja tersebut menggunakan domain air, kriminal, dan sebagai invasi militer. Penggunaan metafora yang berulang-ulang pada editorial tersebut memberikan gambaran tentang realitas yang sebenarnya sehingga mengaburkan batas antara makna literal dan non-literal.

Penelitian lain memfokuskan pada metafora leksikal sebagai ikatan afiliasi dalam editorial surat kabar (Liu, 2018). Melalui perspektif linguistik fungsional sistemik dan metode Critical Discourse Analysis (CDA), ia menemukan bahwa metafora leksikal diakui sebagai sumber daya untuk memberlakukan makna interpersonal dalam diskursus yang difokuskan pada konteks editorial surat kabar. Fungsi persuasif dari metafora leksikal memiliki dugaan aspek positif dan negatif bagi pembaca berdasarkan pengalamannya. Sebutan parlemen sebagai "seat of Batman" menunjukkan peran positif Batman. Selain itu, parlemen merupakan tempat duduk orang yang baik seperti Batman. Sedangkan pada aspek negatif, sebutan untuk pegawai pemerintah adalah sebagai orang yang menghabiskan energi ("people losing energy"). Analisis metafora ini kemudian dihubungkan dengan eksistensi dan posisi kepentingan medianya.

J. David Cisneros (2008) meneliti representasi kaum imigran dalam media yang memfokuskan pada penggunaan metafora dalam menggambarkan retorika permasalahan sosial kaum imigran. Pada penelitian-penelitian sebelumnya dalam media populer seperti televisi, berita imigran ilegal digambarkan sebagai permasalahan yang kompleks. Media menyebut tindakan kaum imigran sebagai tindakan invasi, kriminal, dan sebagai penyakit. Kaum imigran dikatakan sebagai "polusi" yang memiliki makna mengganggu, seperti polusi dalam lingkungan.

Fallah \& Raouf Moini (2016) melakukan analisis perbandingan metafora Arab Uprising pada surat kabar Persia dan Amerika dengan menggunakan kombinasi pendekatan, yaitu kognitif (Lakoff, George and Johnson, 1980) dan pragmatik(Charteris-Black, 2004). Penelitian tersebut dilakukan pada 60 editorial The Washington Post dan The Keyhan pada 2011. Washington Post 
menyebutkan bahwa isu Arab Uprising sebagai "perjalanan" ("Journey") sebab peristiwa itu dianggap sebagai bagian awal rute perjalanan menuju tujuan tertentu dalam demokrasi. Selain itu, pada surat kabar The Keyhan paling dominan digambarkan sebagai konflik keagamaan (religious conflict).

Penelitian lain terkait metafora ialah mengenai metafora perang dengan fokus penelitian pada metafora tentang apa yang digunakan dalam pemberitaan Perang Teluk pada 2003. Metafora dianalisis menurut bahasa Amerika, apakah perang yang terjadi masuk akal, bagaimana peranan metafora, dan bagaimana bahasa mengonsepkan dan mengonstruksi perang (Lule, 2004). Isu Perang Teluk juga diteliti oleh Sahlane dengan menganalisis metafora sebagai retorika pada editorial di media (Sahlane, 2013).

Magaña \& Matlock (2018) melakukan penelitian untuk memahami bagaimana pembicara orang Spanyol memahami kondisi pasien kanker ketika menyampaikan pengalamannya pada orang lain. Dalam penelitian tersebut, pembicara pasien kanker menggunakan metafora untuk menjelaskan kasus yang dihadapinya. Pada hasil penelitian ditemukan bahwa ada dua kategori metafora yang digunakan, yaitu perjalanan dan kejahatan.

Studi terdahulu mengkaji penggunaan metafora dalam berbagai praktik komunikasi, misalnya dalam proses belajar dan diskusi dalam masyarakat. Ada juga studi tentang isi media, misalnya dalam bentuk berita, editorial, dan artikel. Khusus tentang penggunaan metafora dalam editorial media, penelitian terdahulu fokus pada isu-isu tertentu yang berkaitan dengan permasalahan sosial, seperti imigran pencari kerja dan invasi pasukan asing ke suatu negara. Permasalahan yang dikaji adalah tentang penggunaan metafora yang bertolak dari konsep metafora sebagai diksi dalam bahasa dan mentransfer makna dari satu konsep ke konsep lain.

Secara linguistik, filosofis, dan kajian literatur, metafora artinya mengambil alih (to carry offer). Menggunakan metafora artinya mentransfer atau mengalihkan ide atau makna dari satu objek ke objek yang lain untuk memberikan makna yang baru, lebih luas, lebih khusus, dan memberi makna lain yang lebih tepat (Steuter \& Wills, 2008).

Berdasarkan uraian di atas dapat disimpulkan bahwa editorial media massa seyogyanya memberikan makna yang jelas dan konkrit. Namun, editorial media massa cenderung memberikan makna lain, salah satunya menggunakan metafora sebagai kekuatan retorik.

Studi mengenai metafora, khususnya dalam konteks editorial sebagai ruang pendapat media masih jarang dilakukan. Sahlane (2013) meneliti metafora sebagai retorika dalam editorial, tetapi fokusnya pada penelitian posisi media terhadap sikap pro dan kontra invasi Amerika ke Irak pada 2003. Berbeda dengan Sahlane yang fokus penelitiannya tentang kekuatan retorik metafora dilihat dari pola membangun argumentasi dalam editorial.

Rumusan masalah penelitian ini adalah bagaimana metafora sebagai kekuatan retorik disajikan dalam editorial media massa di Indonesia? Tujuan penelitian ini adalah untuk mengidentifikasi posisi metafora dalam struktur editorial dan menjelaskan kekuatan retorikanya. Sebagai karya jurnalistik, editorial memiliki struktur sebagai sebuah opini yang memuat permasalahan, pembahasan atau argumentasi, dan pendapat atau sikap resmi media. Kekuatan retorik akan dianalisis berdasarkan konsep tindakan persuasif dalam retorika menurut Aristoteles, yaitu logos, ethos, dan pathos.

Untuk menjawab masalah penelitian tersebut diteliti dua media massa, yaitu surat kabar Republika dan Media Indonesia. Kedua institusi media tersebut memiliki karakteristik yang berbeda karena perbedaan ideologi sebagaimana tercermin dalam visi media. Surat kabar Media Indonesia mempunyai visi membangun sebuah media independen serta menatap hari esok yang lebih baik (Media Indonesia, 2020). Sedangkan visi surat kabar Republika adalah sebagai media 
umat terpercaya mengembangkan nilai universal dengan prinsip menjaga persatuan bangsa dan umat islam.

Dari rumusan visi tersebut diketahui bahwa surat kabar Media Indonesia lebih menekankan pada karakteristik yang inklusif untuk semua segmen masyarakat. Sedangkan surat kabar Republika, walaupun menyebutkan mengembangkan nilai universal, tetapi terdapat penekanan untuk umat Islam sehingga menunjukkan indikasi eksklusif untuk masyarakat muslim.

Dalam tradisi kajian komunikasi, penelitian ini termasuk dalam tradisi retorika sebagaimana dikemukakan oleh Litlejohn, Stephenson. Fos, Karen A. Oetzel (1917) yaitu studi yang memfokuskan pada persuasi sebagai seni untuk menyusun argumentasi dan pembuatan pidato. Dari lima bidang retorika, penelitian ini berkaitan dengan aspek arrangement yang memberikan perhatian pada proses pengorganisasian simbol dan penyusunan informasi. Metafora merupakan diksi dalam bahasa yang disusun dalam rangkaian kalimat dan ditempatkan dalam struktur editorial serta diperkirakan mempunyai daya pengaruh.

Kajian metafora menurut Kövecses (2010) dikategorikan dalam dua perspektif, yaitu tradisional dan baru. Dari perspektif tradisional, metafora merupakan kelengkapan dari sebuah kata, digunakan untuk memperindah kata, atau menjadikan sebuah pernyataan menjadi lebih artistik dan menarik. Selain itu, metafora juga digunakan untuk memperjelas perbedaan antara dua entitas. Umumnya, metafora digunakan untuk memberikan gambaran tentang suatu kiasan apabila kita tidak bisa menyatakan secara nyata.

Dalam perspektif yang baru, seperti yang dikemukakan oleh Lakoff, George and Johnson (1980) metafora tidak hanya mengenai masalah Bahasa tetapi juga memiliki dimensi kognitif yang disebut cognitive linguistic. Pandangan ini menjelaskan bahwa metafora bukan kelengkapan kata tetapi kelengkapan konsep. Tujuannya adalah untuk bisa lebih memahami konsep metafora dan bukan sekadar aspek artistik dan estetika. Metafora digunakan dalam kehidupan sehari-hari secara mudah dan digunakan oleh orang-orang umumnya tanpa harus memiliki bakat tertentu. Metafora merupakan konsep yang berbasis proses berfikir dan penalaran.

Lakoff, George and Johnson (1980) lebih lanjut menjelaskan bahwa metafora merupakan peta silang domain dalam sistem konseptual. Dalam kognitif linguistik, posisi antara bahasa dan interpretasi terdapat ketergantungan dalam hal ide. Metafora yang memfokuskan pada aspek bahasa digunakan untuk yang pertama kali tetapi sekarang telah dilupakan dan diganti dengan cara melihat metafora sebagai pemikiran (thought).

Konsep silang domain (Lakoff, 2008) ialah penggunaan konsep sebagai domain sumber (source domain) untuk menggantikan konsep lain sebagai domain sasaran (target domain). Sebagai contoh, pernyataan Love is a Journey menggunakan kata "Journey" sebagai domain sumber dan untuk konsep "love" sebagai domain target. Konsep Journey dipetakan menjadi travelers, vehicle, destination, dan impediments to motions. Peta ini berhubungan dengan peta pada love yang meliputi lovers, relationship, life goal, dan difficulties. Jadi, konsep Journey digunakan untuk penggambaran love sebagai sebuah journey. Semua persoalan dalam love dikiaskan dalam permasalahan journey. Gambaran tersebut sejalan dengan kesimpulan Johnson bahwa sebuah metafora mentransfer makna ontologi domain sumber pada domain sasaran sehingga menghasilkan arahan untuk memahami keseluruhan konsep yang digunakan.

Steen (2010) menjelaskan, ada tiga dimensi metafora yaitu nilai komunikasi (communication value), nilai konseptual (conceptual value), dan nilai linguistik (linguistic value). Penggunaan metafora dalam dimensi nilai komunikasi dilihat apakah metafora digunakan secara sengaja (deliberate) atau tidak sengaja (non-deliberte). Pada model deliberate, orang yang mengirim pesan mencarikan metafora dengan menggunakan domain sumber asing yang ditujukan pada sasaran sebagai domain target. Sebaliknya, pada non-deliberate penggunaan metafora tidak memiliki 
tujuan khusus untuk mengubah sasaran. Pada dimensi nilai konseptual, metafora dilihat secara linguistik yang mengacu pada sudut pandang konvensional yaitu hanya dari aspek bahasa dan selanjutnya memosisikan metafora sebagai pemikiran. Pada dimensi nilai linguistik dilihat apakah objek yang diamati tersebut (antara domain sumber dan target) berkaitan secara similar atau dalam konteks metaforik.

Metafora sebagai sebuah pikiran memberikan makna pada suatu subjek yang memiliki kognisi dan diarahkan oleh domain sumbernya. Metafora merupakan upaya untuk memberikan nilai komunikasi yang bisa berpengaruh, sehingga metafora tersebut memberikan kekuatan retorik. Konsep retorik dalam berbagai literatur selalu merujuk pada Aristoteles yang menempatkan retorika sebagai sebuah ilmu pengetahuan dengan secara sistematis mengeksplorasi pengaruh dari pembicara, pidato, dan penonton (Griffin, 2015). Menurut Aristoteles, seluruh pengetahuan ini digunakan sebagai suatu seni dan pengetahuan menempatkan kebenaran sebagai tujuan paling tinggi untuk dicapai. Bagi Aristoteles, retorika merupakan suatu seni yang digunakan agar khalayak menemukan kebenaran yang mungkin tidak sepenuhnya yakin. Pada aspek terakhir inilah terkandung nilai persuasif dari suatu retorika yang berusaha meyakinkan khalayaknya.

Selanjutnya, Aristoteles (Griffin, 2015) mengidentifikasi tiga bentuk tindakan persuasif sebagai unsur retorika, yaitu logos, ethos, dan pathos. Ketiganya saling berkaitan. Logos berkaitan dengan dimensi logis (logika) yang tampak dalam argumen-argumen yang dibangun oleh seorang pembicara. Ethos berkaitan dengan aspek etis yang tampak dalam karakter pembicara yang diungkapkan melalui pesan. Selain itu, pathos berhubungan dengan aspek emosional yang tampak melalui cara bagaimana pembicara melibatkan perasaannya dalam ucapannya sehingga dapat memengaruhi perasaan pendengarnya.

Kata kunci dari retorika ialah memengaruhi yaitu bagaimana seorang komunikator memengaruhi komunikan atau khalayaknya. Argumentasi disusun sedemikan rupa, karakter subjek digambarkan, dan suasana emosional dibangkitkan melalui bahasa, baik verbal maupun nonverbal. Fahnestock (2012) menyebutkan bahwa kata, kalimat, dan suara membangun argumentasi sebagai pemikiran yang bernilai retorika dan persuasi.

Berdasarkan pendapat Aristoteles (Griffin, 2015) menjelaskan bahwa ada lima standar sebagai pedoman dalam melakukan retorika yaitu invention, arrangement, style, memory, dan delivery. Pada tahap invention, pembicara harus menggali topik yang disampaikan dengan menganalisis khalayak untuk menemukan metode yang tepat. Pada fase arrangement, pembicara menyusun struktur dan mengorganisasi teks yang tepat dan yang mudah dipahami khalayak serta bisa mengarahkan jalan pikiran dan emosi khalayaknya. Pada fase style, pembicara harus memilih katakata yang tepat agar bisa memengaruhi komunikannya. Dalam fase ini, peranan penggunaan metafora menjadi penting. Lalu pada fase memory, mensyaratkan kemampuan memory pembicara untuk mengingat apa yang akan disampaikan. Terakhir pada tahap penyampaian (delivery), si pembicara menggunakan semua kemampuan inderanya untuk menyampaikan isi pesannya.

Dalam konteks penelitian ini, retorika dilakukan dalam sebuah tulisan di ruang opini media yaitu editorial di surat kabar Republika dan Media Indonesia. Kedua media tersebut memiliki perbedaan ideologi sehingga menarik untuk diteliti karena penyajian gaya retorikanya berbeda.

Sebagai genre komunikasi, penggunaan metafora dalam editorial kemungkinan terjadi secara tidak sengaja (non-deliberate) ketika metafora digunakan hanya sebagai kelengkapan kata. Naman, ketika retorika masuk dalam editorial tentu menuntut penggunaan metafora secara sengaja (deliberate) untuk memosisikan domain sasaran yang menyiratkan gambaran tertentu yang diinginkan. Dalam posisi ini penggunaan metafora tidak saja menunjukkan makna yang sesuai atau serupa (similar), tetapi juga membangun makna metaforik yang mengkonstruksi sebuah pikiran tentang domain sasaran tersebut dari objek yang diteliti melalui bahasa. 
Sebagai karya jurnalistik, editorial berbeda dengan karya jurnalistik lainnya, misalnya berita. Berita berisi fakta tentang peristiwa dan atau fakta tentang pendapat dari narasumber. Berita tidak boleh mengandung opini wartawan, sedangkan editorial mengandung pendapat dari redaksi media tersebut tentang suatu persoalan yang aktual. Editorial adalah pernyataan dan sikap resmi media massa sebagai sebuah lembaga atas suatu hal yang penting dan aktual.

Menurut Wolseley (1969) editorial adalah karangan singkat yang merupakan opini yang mempersuasi atau artikel yang argumentatif. Kemudian, menurut Sumadiria (2004), editorial merupakan opini redaksi yang berisi aspirasi, pendapat, dan sikap resmi media massa terhadap persoalan potensial, fenomenal, aktual, dan atau kontroversial yang terjadi di tengah-tengah masyarakat. Opini yang ditulis redaksi diasumsikan mewakili sekaligus mencerminkan pendapat dan sikap resmi media massa yang bersangkutan secara keseluruhan.

Fungsi editorial adalah 1) mendorong pembentukan pendapat umum secara kreatif, kritis, dinamis, dan konstruktif; 2) menjadi tempat resmi penyaluran pendapat, penjelasan, dan penjernihan fakta dalam berita; 3) menunjukkan apa yang menjadi perhatian pembaca dan bagaimana reaksi mereka; 4) mengembangkan tanggung jawab sosial surat kabar agar selalu mawas diri sebagai panutan; 5) mengemukakan analisis dan penjelasan dalam menyiapkan kondisi tertentu bagi pengembangan masyarakat; dan 6) menjelaskan berita, latar belakangnya, memprediksi masa depan, dan menyampaikan pertimbangan moral (Sumadiria, 2004).

Editorial disajikan di media massa bertujuan untuk memberitahu, menjelaskan, mendidik, dan memengaruhi pembaca. Editorial juga menawarkan sebuah pendapat dan sekaligus memengaruhi pembaca agar menerima pendapat tersebut. Dengan demikian, penulis editorial dan pembaca dapat menghimpun kekuatan untuk melakukan perubahan, menghilangkan kesulitan, dan melindungi suatu keadaan tetap pada waktu tertentu (status quo). Editorial mengetengahkan garis kebijakan (policy) dari surat kabar yang bersangkutan dengan tujuan memengaruhi dan memperjelas hal-hal yang berkaitan dengan berita dan isu-isu yang muncul pada waktu itu. Editorial merupakan jiwa dari surat kabar.

Ketika redaksi memilih topik yang akan disajikan, faktor yang perlu dipertimbangkan redaksi adalah 1) seberapa besar pengaruh terhadap pembaca; 2) penting tidaknya dibandingkan dengan topik lain; 3) perlu atau tidak mengambil sikap terhadap isu tertentu; 4) aktualitas; dan 5) proximity (kedekatan). Selain itu, sumber editorial adalah dari berita, hasil penelitian, informasi dari wartawan, dan sebagainya. Struktur atau anatomi editorial ada tiga bagian, yaitu 1) anatomy of attention; 2) anatomy of conviction; dan 3) anatomy of direction (Sumadiria, 2004).

Pertama, anatomy of attention atau kepala editorial. Bagian ini bertujuan untuk menarik perhatian pembaca yang terdiri atas judul dan pendahuluan (lead). Bahasa yang digunakan pada judul adalah pernyataan yang disusun secara jelas. Pada pendahuluan ditetapkan sudut pandang atau sikap dari redaksi terhadap pernyataan tersebut. Pendahuluan (lead) berisi inti terpenting dari editorial. Pada pendahuluan redaksi menarik perhatian pembaca antara lain dengan cara menggunakan kata-kata yang menggugah, mengutip ucapan tokoh atau pejabat, mengemukakan kontroversi secara statistik, mengutip bagian tertentu dari suatu peristiwa, atau mengemukakan analogi suatu topik.

Kedua, anatomy of conviction, atau tubuh editorial. Bagian ini bertujuan untuk memengaruhi pembaca dengan cara mengungkapkan analisis terhadap topik yang dikemukakan di anatomy of attention, termasuk analisis terhadap sudut pandang atau sikap media massa yang bersangkutan. Isi anatomy of convention adalah a) pendapat orang yang punya otoritas, seperti pejabat, tokoh masyarakat, para ahli; b) uraian logis atas hipotesis yang diungkap; c) uraian tentang peristiwa penting yang aktual, atau pengalaman redaksi atau masyarakat yang bisa dipercaya; d) pemecahan 
masalah secara khas atas persoalan yang muncul; dan e) gambaran visual yang mendukung (kartun, ilustrasi, grafik, dan sebagainya).

Ketiga, anatomy of direction atau kaki editorial. Bagian ini berisi conclusion, yaitu bagian yang memberi saran, anjuran, atau solusi untuk melakukan sesuatu. Isi anatomy of direction, berupa a) kesimpulan uraian peristiwa yang dianalisis; b.) pengulangan kembali hipotesis; c) beberapa solusi sebagai pemecahan; d) fakta atau data yang mengingatkan kembali pada isi anatomy of attention; e) peringatan atau ramalan untuk kepentingan pembaca; dan f) ungkapan atau pernyataan simpati, mendukung, penyesalan, atau penolakan terhadap sesuatu. Bahasa yang digunakan dalam editorial adalah gaya bahasa yang hidup, lincah, segar, jelas, singkat, populer, mengandung metafora dengan tetap merujuk pada kaidah bahasa baku.

Tiga anatomi suatu editorial yaitu attention, conviction, dan direction merupakan struktur retorik yang berusaha meyakinkan dan mengarahkan opini yang akan dibangun. Menurut Van Dijk (1980), sebagai sebuah wacana editorial mengemukakan pandangan tentang baik buruknya lembaga public misalnya parlemen, pengadilan, dan kementerian.

Selanjutnya, Ansary dan Babaii (2005) melakukan penelitian mengenai struktur retorika editorial. Ia mengemukakan elements of English editorials yaitu run-on headline, addressing an issue, argumentation and articulating a position, in the editorials and also three optional elements (providing background information, initiation of argumentation, and closure of argumentation).

Setiap media massa memiliki gaya penulisan editorial yang berbeda dengan media massa lainnya. Hal ini sesuai dengan kebutuhan pembacanya yang bisa mendekatkan dengan hati nurani pembacanya, dan tergantung pada budaya masyarakatnya yang dimanifestasikan dalam bahasa (Zarza \& Tan, 2016). Dalam penelitian ini, struktur yang akan dijadikan kerangka analisis dalam melihat posisi metafora yang generik adalah struktur attention, conviction, dan direction.

\section{METODE PENELITIAN}

Penelitian ini menggunakan paradigma konstruktivis yaitu paradigma yang memandang realitas dalam penelitian sebagai suatu yang dikonstruksi secara lokal dan spesifik. Temuan penelitian diciptakan melalui proses transaksional dan subjektif (Guba, Egon G and Lincoln, 2005), Realitas yang diteliti adalah mengenai retorika dari metafora dalam editorial media massa. Hal ini merupakan sebuah konstruksi yang dibangun oleh redaksi media massa yaitu Surat kabar Republika dan Media Indonesia. Peneliti melakukan penafsiran makna objek berdasarkan makna sumber metafora.

Sejalan dengan paradigma yang digunakan, pendekatan untuk mengkaji metafora dalam editorial media massa di Indonesia ialah pendekatan kualitatif. Melalui pendekatan ini, temuan penelitian didasarkan pada subjek penelitian, yaitu teks-teks metafora dalam editorial yang dikaitkan dengan kekuatan retorik. Temuan penelitian digambarkan secara deskriptif melalui katakata tertulis yang diamati dan peneliti akan menemukan makna-makna unik yang tidak bisa digeneralisasikan (Moleong, 2011)

Metode penelitian yang digunakan ialah analisis teks Metaphor Identification Procedure (MIP) yang dikemukakan Pragglejaz sebagaimana yang dijelaskan oleh Kövecses (2010). Prosedur yang dilakukan meliputi lima tahap yaitu: 1) membaca seluruh teks untuk mendapatkan pemahaman secara utuh; 2) memilah dan menentukan satuan-satuan leksikal di dalam teks; 3) memperhatikan makna satuan-satuan leksikal teks di dalam konteks secara keseluruhan berdasarkan situasi teks (makna kontekstual); 4) menentukan apakah satuan leksikal memiliki makna yang lebih konkret dengan membandingkan maknanya dengan arti yang ada di dalam kamus; dan 5) menandai satuan-satuan leksikal sebagai sebuah metafora. 
Teks yang diteliti ialah editorial surat kabar Republika dan Media Indonesia. Secara ideologis kedua media tersebut memiliki latar belakang yang berbeda. Editorial yang diteliti adalah yang diterbitkan kedua surat kabar tersebut edisi 1 Juli sampai 31 Agustus 2019, yang menggunakan metafora dalam isinya. Rentang waktu tersebut dipilih karena pada saat itu Presiden Joko Widodo dan Wakil Presiden Ma'ruf Amin yang terpilih pada pemilihan umum 2019 sedang menyusun kabinet untuk periode 2019-2024.

Setelah dilakukan identifikasi secara purposive sampling, dipilih lima editorial yang terdiri atas satu editorial surat kabar Republika dan empat editorial Media Indonesia. Editorial di Surat kabar Republika menggunakan istilah "Tajuk Rencana", sedangkan di Media Indonesia menggunakan istilah "Editorial".

Analisis data difokuskan untuk menemukan kekuatan retorika metafora yang digunakan dalam editorial. Kekuatan retorika akan dilihat dari posisi metafora yang digunakan dalam struktur editorial yaitu judul, attention, conviction, dan direction. Analisis metafora dibagai dalam dua bagian. Pertama, untuk melihat apakah hanya sebagai ilustratif dalam pandangan tradisional metafora. Kedua, untuk melihat apakah metafora memiliki makna lebih dalam hal ini sebagai pikiran yang memberikan makna khusus yang bernilai persuasif.

Berdasarkan Metaphor Identification Procedure, dilakukan beberapa hal yakni membaca editorial yang menjadi bahan penelitian, menemukan kata-kata yang termasuk kategori metafora, serta memahami penggunaan metafora tersebut dalam konteks kalimat, paragraf, dan keseluruhan editorial. Pada tahap ini dilakukan analisis makna metafora dengan melakukan pemetaan skema konseptual metafora (Kövecses, 2010) dengan cara mengidentifikasi domain sasaran (target domain) dan domain sumber (source domain) metafora. Ungkapan-ungkapan metafora yang sudah diidentifikasi skema kognitifnya pada domain sumber digunakan untuk menjelaskan makna pada domain sasaran. Kemudian hasil analisis dihubungkan dengan posisi metafora pada struktur anatomi editorial yang meliputi attention, conviction, dan direction untuk menganalisis kekuatan retorika dalam editorial.

Untuk menunjukkan akurasi dan kredibilitas temuan, dilakukan proses triangulasi. Menurut Denzin sebagaimana dikutip oleh Patton (2002), dalam penelitian kualitatif ada empat macam triangulasi yaitu triangulasi sumber data, triangulasi teori, triangulasi investigator (peneliti), dan triangulasi metodologi. Dalam penelitian ini digunakan triangulasi sumber data yaitu data editorial Surat kabar Republika dan Media Indonesia. Dari segi isu, dijelaskan juga bagaimana kedua media massa tersebut menggambarkan isunya dan metafora apa yang digunakannya.

\section{HASIL DAN PEMBAHASAN}

Editorial media merupakan arena opini media dalam menyikapi isu-isu yang diberitakannya. Editorial media memiliki kedaulatan untuk menyampaikan posisinya dengan menjelaskan dan memberikan argumentasi, pendapat, serta sikap resmi redaksi. Dalam pernyataan sikap editorial media bisa memberikan arahan dan usulan. Sasarannya bisa kepada subjek yang menjadi bagian dari isu dan bisa juga kepada masyarakat, yakni mengajak masyarakat untuk berpartisipasi. Struktur argumentasi dan bahasa yang digunakan dalam editorial media merupakan strategi media dalam memengaruhi subjek isu dan masyarakat. Bagaimana editorial bisa memberikan pengaruh, merupakan esensi dari retorika yang indikator awal keberhasilannya bisa dilihat dari isi pesan yang disampaikannya. Strategi retorika dilakukan dalam editorial melalui struktur anatomi editorial dan melalui penggunaan bahasa yang salah satunya menggunakan metafora.

Mengacu pada esensi retorika sebagai upaya memengaruhi, maka mengkaji metafora dalam editorial mengandung peranan retorika ganda. Metafora merupakan diksi dalam bahasa yang digunakan untuk memberikan makna khusus terhadap objek yang menjadi sasaran. Makna khusus 
tersebut mengandung pesan persuasif yang diharapkan dapat memberikan pengaruh pada pembacanya. Editorial yang menjadi subjek penelitian ini merupakan genre opini dalam media. Editorial tersebut dirancang untuk memberikan opini dan menunjukkan sikap redaksi terhadap isu yang menjadi pemberitaan dalam media. Editorial disusun sebagai sebuah retorika. Retorika dalam editorial bisa dilihat dari struktur argumentasi dan bahasa yang digunakan untuk mengkonstruksi isu yang dibahas.

\subsection{Kabinet sebagai Kendaraan}

Setelah pengumuman tentang presiden dan wakil presiden hasil Pemilihan Umum 2019 oleh Komisi Pemilihan Umum (KPU), Redaksi Republika pada edisi Juli 2019 membuat editorial yang mengemukakan analisis dan pendapat tentang kabinet yang akan dibentuk oleh presiden dan wakil presiden terpilih. Republika dalam editorialnya menggunakan judul "Kabinet Baru Tancap Gas". Editorial ini menggunakan metafora dari "unsur kendaraan", yaitu "pedal gas" dan "ban". Jika dipetakan, sebagai domain sumber adalah kendaraan dan sebagai domain sasaran adalah kabinet pemerintahan baru yang akan dibentuk. Kendaraan memiliki unsur antara lain sopir yang mengendalikan mobil, ban mobil dan roda yang membawa mobil itu berjalan, pedal rem dan pedal gas yang akan mengendalikan kendaraan tersebut, dan kapan pedal rem dan pedal gas harus diinjak.

Dalam uraian isi editorial tersebut dijelaskan, "Presiden dan menteri-menteri harus mampu tancap gas langsung menjalankan program-program tersebut." Di bagian akhir editorial Republika ditulis "Sejak awal di sini peran Wapres KH Ma'ruf Amin harus bisa dioptimalkan. Bukan sekadar sebagai ban serep, apalagi hanya sebagai pasangan."

Pada struktur retorik, metafora yang digunakan dalam editorial Republika ada pada anatomy of attention, anatomy of conviction, dan anatomy of direction. Judul "Kabinet Baru Tancap Gas" merupakan bagian dari struktur retorika untuk menarik perhatian pembaca pada isu yang akan dikemukakan yaitu kabinet baru yang akan disusun oleh presiden terpilih. Selanjutnya, kalimat "Presiden dan menteri-menteri harus mampu tancap gas langsung menjalankan program-program tersebut" ada pada struktur conviction. Ini menjadi bagian dari struktur untuk meyakinkan pembaca tentang apa yang dilakukan oleh para menteri setelah dipilih presiden.

Dalam teks sebelum kalimat tersebut terdapat uraian tentang permasalahan yang dihadapi oleh pemerintah sebelumnya. Kata "harus" dalam kata-kata "harus tancap gas" merupakan prasyarat nilai kompetisi yang harus dimiliki oleh Presiden Jokowi dan para menteri. Pada tahap direction, Republika memberikan saran agar semua sumber daya digunakan. Lalu, dalam bagian terakhir terdapat metafora "ban serep" yang ditujukan kepada wakil presiden terpilih agar tidak dijadikan hanya sebagai cadangan apabila diperlukan. Sebagaimana fungsi dari ban serep, pengarahan ini merupakan kritik karena sebelumnya berkembang pendapat umum di tengah masyarakat bahwa ada kekhawatiran bahwa Wakil Presiden Ma'ruf Amin tidak dimanfaatkan secara optimal.

Metafora "tancap gas” juga digunakan dalam editorial Media Indonesia 15 Agustus 2019. Berdasarkan tanggal pemuatan editorial ini, konteks yang menjadi domain sumber ialah elemen atau unsur dari kendaraan yaitu pedal gas dan domain targetnya ialah kabinet baru yang akan dibentuk. Metafora yang digunakan Surat Kabar Media Indonesia dalam struktur retorika ialah pada unsur attention dengan membuat judul "Agar Kabinet Tancap Gas". Metafora juga terdapat pada struktur direction dengan pernyataan "Setelah itu, begitu dilantik, mereka bisa tancap gas dalam menjalankan roda pemerintahan".

Pada uraian argumentasinya dikemukakan, seperti apa menteri-menteri yang sebaiknya dipilih dan apa yang harus dilakukan oleh para menteri sebelum dilantik. Dikemukakan juga bahwa menteri-menteri menyiapkan program kerja sehingga setelah dilantik bisa langsung bekerja. Kata 
"tancap gas" menyiratkan imbauan bahwa pemerintah tidak hanya berjalan tetapi jalannya harus cepat. Metafora ini sesuai dengan pernyataan dalam kalimat sebelumnya bahwa presiden terpilih menyampaikan, unsur kecepatan menjadi penting dalam menghadapi persaingan global.

\subsection{Kursi Panas Ketua MPR}

Pada editorial Media Indonesia yang berjudul "Kursi Panas Ketua MPR" terdapat metafora "kursi" dan "panas". Keduanya memiliki domain sumber dan sasaran berbeda namun ditujukan pada satu objek yang sama yaitu Ketua Majelis Permusyawaratan Rakyat (MPR). "Kursi" sebagai konsep fisik berarti tempat duduk. Secara fisik kursi memiliki ragam kategori baik menurut bentuk, peruntukan (fungsi), kekuatan kursi, posisi kursi dalam ruangan atau gedung, dan estetika kursi. Jadi, yang melekat dalam metafora "kursi" secara fisik adalah sesuatu yang memiliki nilai posisi, variasi, fungsi atau peruntukan, serta estetika. Domain sumber ini digunakan untuk jabatan ketua MPR sebagai domain sasaran. Jika dilihat berdasarkan makna kursi pada domain sumber, jabatan ketua MPR tersebut menunjukkan kursi yang diperoleh dan memiliki posisi yang bisa saja penggunaannya bervariasi.

Metafora "panas" merupakan konsep keadaan yang memiliki variasi karakter. Bagi manusia, konsep "panas" bisa merupakan hal yang membuat nyaman atau tidak, memiliki kekuatan atau tidak, dan memiliki peminat atau tidak. Kemudian, kata "panas" dijadikan untuk menggambarkan kursi sebagai jabatan. Dengan demikian, kursi yang digambarkan sebagai jabatan tersebut dicari dan dikejar oleh para aktor politik. Disebut "panas" karena memiliki makna yang menyiratkan adanya pergolakan seperti air yang dalam proses pemanasan airnya akan bergolak. Kursi yang panas juga bisa menyebabkan siapa pun yang duduk di kursi tersebut akan menimbulkan permasalahan yang bisa membuat orang tersebut nyaman atau tidak nyaman.

Konteks "kursi panas ketua MPR" dilihat dari isi editorial terdapat pada struktur yang bertujuan untuk membangkitkan perhatian, yaitu attention. Hal ini memberikan gambaran permasalahan tentang jabatan Ketua MPR yang belum terisi. Dalam proses mengisi jabatan tersebut terjadi pertarungan di antara elit politik dan orang-orang yang melakukan upaya-upaya lobi politik, transaksi politik, dan lain-lain. Mengenai hal ini, media melakukan pembahasan dan menganalisisnya untuk meyakinkan pembaca bahwa perebutan kursi tersebut tidak sehat. Selanjutnya dalam struktur direction, Media Indonesia menyarankan agar para elit politik yang ada di masing-masing fraksi memikirkan aspek substantif untuk mengembangkan ide dan program membangun bangsa dan tidak mengedepankan kekuatan pribadi dan kelompok.

Metafora yang digunakan dalam retorika pada tahap attention yaitu pada judul editorial dan bagian penjelasan keadaan atau isu dengan pernyataan "Kursi pimpinan MPR sudah panas bahkan sebelum diduduki". Maksud kalimat tersebut adalah jabatan Ketua MPR sudah menjadi masalah sebelum jabatan itu diemban oleh ketua MPR. Permasalahannya ialah terjadi perebutan dan pertarungan antara elit politik untuk mendapatkan kursi Ketua MPR.

\subsection{Korupsi sebagai Penyakit dan Wajah Dewan yang Kusam dan Bopeng-Bopeng}

Masalah korupsi di Indonesia menjadi perhatian media dalam tiga hal yaitu tentang kinerja instansi Komisi Pemberantasan Korupsi (KPK) yang isunya jadi meluas, tentang penyempurnaan Rancangan Undang-Undang KPK, dan tentang perilaku koruptor baik pejabat pemerintah maupun elit politik.

Untuk masalah kinerja instansi KPK, metafora yang digunakan ialah "penyakit" yaitu perilaku korupsi sebagai penyakit yang harus diobati. "Korupsi merupakan penyakit yang tak kunjung sembuh dengan obat lama yaitu penindakan" (Media Indonesia, 21 Agustus 2019). Dengan demikian ada metafora "penyakit" dan "obat" ("obat lama" dan "obat baru"). Sebagai domain 
sumber adalah penyakit dan domain sasaran adalah korupsi. Peta kognisi tentang penyakit menunjukkan satu kondisi manusia yang tidak sehat dan mengidap penyakit.

Menurut Kamus Besar Bahasa Indonesia (KBBI) Online, penyakit merupakan sesuatu yang menyebabkan terjadinya gangguan pada makhluk hidup, gangguan kesehatan yang disebabkan oleh virus, bakteri, atau kelainan sistem faal, atau kebiasan buruk yang bisa mendatangkan keburukan. Dengan demikian korupsi dianggap suatu kondisi organisasi negara dalam gangguan, apakah karena bibit penyakit sebagai virus atau bakteri. Dalam konteks editorial ini virus dan bakteri merupakan perilaku dan gaya hidup dalam berpolitik negara. Bagian awal editorial Surat kabar Media Indonesia merupakan retorik unsur attention yakni membuka perhatian pembaca dengan suatu pernyataan bahwa korupsi sulit disembuhkan. Penyembuhnya adalah obat. Dikemukakan bahwa obat yang selama ini digunakan dengan suatu tindakan dinilai tidak cocok dan sudah saatnya diganti dengan obat pencegahan.

Editorial Media Indonesia yang kedua menyoroti praktik korupsi di parlemen yang bersumber dari berita tentang vonis sidang Tindak Pidana Korupsi (Tipikor) terhadap salah seorang anggota Dewan Perwakilan Rakyat (DPR). Anggota DPR tersebut dihukum selama 6 tahun. Selain itu ada juga laporan KPK pada Komisi III DPR. KPK mengatakan bahwa selama rentang waktu tahun 2014 sampai 2019 jumlah korupsi yang terjadi paling banyak di DPR. Ada dua editorial yang terkait dengan pelaku korupsi dengan judul "Terpuruk karena Pimpinan Korup" (dimuat 16 Juli 2019) dan "Wajah Kusam Dewan" (dimuat 4 Juli 2019).

Pada editorial pertama terdapat beberapa metafora yang digunakan pada kalimatnya dan posisinya terdapat dalam struktur editorial. Kalimat pertama editorial yang memiliki fungsi penarik perhatian pembaca ialah "Lengkap sudah coreng DPR kita". Kata "coreng" dalam kalimat pembuka editorial tersebut artinya adalah garis besar tebal, contreng, dan coret (KBBI Online). Kata ini biasa digunakan untuk menandai adanya suatu kesalahan dalam sebuah ungkapan baik dalam bentuk kata, frase, kalimat, atau gambar. Kata "coreng DPR kita" menunjukkan kesalahan DPR. Tidak saja sebagai makna kesalahan DPR tetapi sudah lebih jauh yaitu gambaran buruk lembaga DPR.

Sebagai bagian struktur conviction yaitu untuk meyakinkan pembaca tentang permasalahan korupsi anggota DPR terdapat dalam kalimat selanjutnya. Peristiwa tindak korupsi tersebut terjadi di tingkat kabupaten dan terhubung dengan oknum anggota DPR Pusat. Editorial Media Indonesia melakukan evaluasi dengan menggunakan metafora "busuknya rantai suap". "Rantai" sebagai konsep domain sumber digunakan dalam menggambarkan keterkaitan antara korupsi di tingkat kabupaten dengan tingkat Pusat dengan sebutan rantai suap. Kata "rantai" dalam KBBI Online diartikan sebagai tali yang berkaitan dan biasanya terbuat dari logam, plastik, dan sebagainya. Kata rantai juga bisa diartikan sebagai pertalian, ikatan, belenggu, kungkungan, dan kekuasaan. Penggunaan metafora "rantai" menunjukkan bahwa praktik korupsi tidak saja dilakukan oleh oknum di suatu daerah dengan oknum pejabat di daerahnya, tetapi juga oleh pihak swasta dan pimpinan DPR Pusat. Dalam hal ini ada ikatan atau pertalian di antara mereka. Keterkaitan ini dimaknai sebagai "ikatan busuk" dalam arti "berbau tidak sedap" dan "kondisi rusak". Praktik korupsi ini dilakukan oleh oknum pejabat daerah dan pimpinan parlemen.

Surat kabar Media Indonesia menyebutnya sebagai "permainan kotor". Pernyataan tersebut merupakan label sebagai permainan kotor. Dalam KBBI Online dijelaskan, permainan merupakan sesuatu yang digunakan bermain atau barang yang dipermainkan. Artinya Media Indonesia ingin mengatakan bahwa dalam masalah korupsi, uang negara dipermainkan dan tidak digunakan sesuai peruntukannya.

Selanjutnya editorial Media Indonesia menguraikan bahwa kasus Setya Novanto dan Taufik ibarat puncak gunung es dari bobroknya wakil rakyat. Disini kata "gunung es" merupakan metafora yang menunjukkan bahwa ada masalah yang tersembunyi dan sangat besar seperti gunung es. Kata 
"bobrok" dalam KBBI Online dikatakan sebagai keadaan yang sama sekali rusak atau bejat. Dengan demikian penggambaran dengan metafora "gunung es" tersebut menunjukkan bahwa jumlah anggota DPR yang melakukan tindakan korupsi sangat banyak jumlahnya, namun tidak tampak. Hal tersebut sangat dikhawatirkan oleh Media Indonesia karena DPR seharusnya menjadi lembaga yang mampu mencegah terjadinya korupsi.

Dalam kalimat berikutnya Media Indonesia menulis, "pejabat DPR mestinya menjadi benteng terakhir". Kata "benteng" merupakan metafora. Sebagai domain sumber ialah kata "benteng" dan domain sasarannya adalah kata DPR. Benteng dalam KBBI Online merupakan "bangunan tempat berlindung" atau "bertahan dari serangan musuh". Artinya, anggota DPR seharusnya bisa menahan godaan agar tidak melakukan korupsi.

Editorial berikutnya berisi mengenai korupsi di kalangan anggota DPR yang bermula dari laporan KPK tentang korupsi di Indonesia. Judul editorial di Media Indonesia tersebut "Wajah Kusam DPR". Judul yang disajikan merupakan ungkapan retorik di bagian struktur attention. Dalam judul tersebut domain sumber metafora berasal dari konsep "wajah manusia". Wajah manusia bisa menampilkan karakteristik manusia dan bisa juga mengekspresikan berbagai kondisi manusia itu sendiri. Wajah manusia dapat mengekspresikan bahwa mereka dalam keadaan sedih, gembira, takut, gelisah, tenang, nyaman, kusam, atau cerah. Menurut KBBI Online kata "kusam" memiliki arti tidak berkilau, tidak bercahaya, muram, dan tidak berseri-seri. Dengan demikian, judul editorial tersebut memberikan gambaran bahwa "kondisi parlemen dalam keadaan negatif".

Dalam argumentasi sebagai unsur editorial conviction, Media Indonesia menjelaskan bahwa "tidak mudah mengubah wajah buruk Dewan". Metafora "wajah" dengan gambaran lain juga dikemukakan oleh Media Indonesia ketika Media Indonesia mengemukakan harapannya, yaitu dengan kalimat "Kita tak ingin wajah parlemen bopeng-bopeng". Di sini tidak lagi menggunakan kata "kusam" tapi dengan kata "bopeng-bopeng". Dalam KBBI Online kata bopeng memiliki arti cacat yang berupa belubang-lubang (lekuk-lekuk) kecil pada kulit, burik, dan capuk. Artinya, gambaran lembaga DPR tidak saja gambaran ekspresi yang tidak cerah, tetapi kondisinya lebih buruk lagi. Anggota DPR merupakan orang-orang yang melanggar etika dan bahkan bisa dikategorikan memiliki kesalahan.

Metafora lain yang digunakan sebagai bagian dari unsur pembuktian atas analisis adalah dengan memberikan pernyataan, "Parlemen selalu jadi juara korupsi". Kata "juara" berasal dari domain hasil kompetisi atau pertandingan yang digunakan untuk domain sasaran perbandingan tentang tingkat korupsi yang dilakukan antar lembaga seperti yang dilaporkan KPK ketika Rapat Dengar Pendapat dengan Komisi III DPR. Juara dalam kompetisi merupakan pemenang yang menunjukkan keunggulan dari orang yang menjadi juara tersebut. Namun kata "juara" sebagai metafora dalam jumlah orang yang melakukan korupsi menjadi sindiran kepada anggota DPR. Kata "juara” juga sekaligus memberikan kekuatan retorik untuk menggambarkan bahwa anggota DPR tidak berkualitas karena banyak yang melakukan korupsi.

Di bagian akhir editorial Media Indonesia disajikan metafora "kusam" dan lawan katanya "cerah". Terdapat kalimat "Sudah lama wajah kusam dewan dibiarkan dan sudah saatnya diubah jadi cerah". Bagian penutup ini memberikan direction kepada pimpinan DPR dan anggotanya untuk mengubah parlemen dari wajah kusam menjadi wajah yang cerah. Dalam tataran pemikiran, hal ini memberikan pengarahan atau tuntutan kepada anggota DPR agar mereka bersih dari perilaku korupsi. Mereka harus menjalankan fungsinya sebagai anggota DPR sehingga dapat membawa masyarakat dan bangsa Indonesia menjadi lebih sejahtera.

Berdasarkan hasil analisis semua editorial di atas ada dua isu yang dikemukakan. Pertama, tentang susunan kabinet yang akan dibentuk. Isinya berupa pendapat media tentang harapan masyarakat terhahap kabinet yang dibentuk presiden dan wakil presiden hasil pemilihan umum 
2019. Kedua tentang korupsi, baik mengenai instansi KPK maupun mengenai tindakan korupsi yang dilakukan anggota DPR dan implikasinya terhadap lembaga DPR.

Kaitan antara anatomi editorial (attention, conviction, dan direction) dengan tindakan persuasif (logos, etos, dan pathos) secara parsial dapat dilihat dari posisi metafora yang digunakan. Aspek judul editorial dan bagian pendahuluan editorial yang tercakup dalam attention merupakan dimensi pathos karena bagian ini harus membangkitkan ketertarikan pembaca terhadap editorial agar pembaca mau membaca editorial sampai selesai. Dalam penelitian ini, misalnya terdapat pada penggunaan metafora "kursi panas ketua MPR". Metafora tersebut dapat membangkitkan emosional pembaca sehingga pembaca tertarik untuk membacanya. Bahkan pada bagian pendahuluan editorial terdapat kalimat "Kursi pimpinan MPR sudah panas bahkan sebelum diduduki", sehingga pembaca tertarik untuk membaca editorial tersebut sampai akhir.

Kalimat "Kursi pimpinan MPR sudah panas bahkan sebelum diduduki" yang ditempatkan pada bagian awal atau pengantar editorial (dalam anatomi attention) sama dengan temuan penelitian tentang perbedaan kecenderungan struktural antara editorial surat kabar Jepang dengan kolom di halaman muka bahwa metafora sering digunakan pada bagian awal tulisan (KatoYoshioka, 2016).

Unsur logos, titik beratnya ada pada struktur yang kedua yaitu conviction. Pada bagian ini dikemukakan argumentasi atau jalan pikiran untuk menjawab permasalahan yang dihadapi. Selain itu unsur logos juga terdapat pada bagian kesimpulan yang merupakan unsur direction, yaitu bagaimana editorial media bersikap dan memberikan saran atau pemecahan masalah. Misalnya pada kalimat "tidak mudah mengubah wajah buruk Dewan", yang dimaknai sebagai pernyataan pemecahan masalah yang sulit dilakukan. Kalimat "Parlemen selalu jadi juara korupsi" merupakan bagian dari penjelasan bukti (evident) tentang kondisi tingkat korupsi di DPR. Sedangkan pada kalimat "Kita tak ingin wajah parlemen bopeng-bopeng" menunjukkan tentang harapan atau direction media pada lembaga DPR.

Penggunaan kata metafora "obat lama" (melalui penindakan) dan "obat baru" (pencegahan) dalam mengurangi bahkan menghilangkan korupsi merupakan penggunaan metafora argumentatif rasional. Metafora "obat" juga digunakan sebagai argumentasi dalam hasil penelitian tentang editorial mengenai perang di Irak pada 2003 di 6 surat kabar yaitu 2 surat kabar di United Kingdom, 2 di Amerika Serikat, dan 2 di Perancis. Media tersebut menyebut "war is the best medicine" (Sahlane, 2013).

Saran pemecahan masalah juga bisa termasuk dalam pathos karena editorial harus mampu membangkitkan emosi pembaca agar mereka mempunyai sikap sesuai dengan sikap redaksi media tersebut. Misalnya pada akhir editorial dikemukakan, "Sudah lama wajah kusam dewan dibiarkan dan sudah saatnya diubah jadi cerah". Dimensi ethos akan berkaitan dengan aspek kredibilitas sumber dan dalam editorial akan melekat pada komunikatornya. Dalam hal ini, komunikatornya adalah media itu sendiri dan juga narasumber yang menjadi rujukan. Metafora yang digunakan akan terkait pada metafora yang dilekatkan sebagai domain sasaran. Dalam analisis ini tidak ditemukan metafora yang dikaitkan langsung dengan narasumber karena dalam semua editorial tidak ada kutipan pendapat dari narasumber.

Dari seluruh metafora yang digunakan dalam editorial Surat Kabar Republika dan Media Indonesia, domain sumber yang digunakan kedua media tersebut berupa: a) benda fisik bergerak, yaitu kendaraan (pedal, gas, dan ban); b) benda fisik tidak bergerak tetapi memiliki karakter, yaitu kursi; c) bagian dari tubuh manusia, yaitu wajah; dan d) hasil kompetisi pada juara korupsi. Penggunaan metafora tersebut mengkonstruksi domain sasaran yang menyiratkan makna dan memiliki daya pengaruh. Pembaca tidak hanya mampu menghubungkannya dengan realitas secara lebih tepat tetapi juga dapat menimbulkan sumberdaya untuk menginterpretasi sebagai sebuah 
pikiran tentang isu yang menjadi perhatian. Selain itu, penggunaan metafora dapat mendorong pembaca untuk mengkonstruksi pikiran. Ketika menyebut "harapan wajah kusam DPR bisa menjadi cerah", hal ini dapat memberikan pemikiran yang harus dibangun yaitu bagaimana agar DPR bisa bangkit dan dapat memberikan kontribusi positif pada kemajuan bangsa Indonesia.

Semua metafora tersebut berada dalam struktur anatomi editorial attention, conviction, dan direction yang menjadi kekuatan retorik editorial dengan memperkuat dimensi logos dan phatos. Metafora yang digunakan dalam isu kabinet baru memberikan peringatan dan tuntutan tentang kabinet yang akan disusun. Metafora tentang korupsi, membangun gambaran dan pemikiran bahwa parlemen yang ada tidak memiliki legitimasi sebagai wakil rakyat. Dengan menggunakan metafora dalam editorial, selain dapat membangun makna yang memiliki pengaruh terhadap pikiran pembaca, juga dapat memperkuat pengaruh struktur editorial dalam membangun logos dan phatos. Dengan demikian, secara teoritis dapat dirumuskan bahwa penggunaan metafora dalam editorial telah memperkuat retorika editorial menjadi retorika ganda (double rhetoric).

\section{PENUTUP}

Surat kabar Republika dan Media Indonesia sama-sama menggunakan metafora dalam editorialnya. Isu yang menjadi sorotan media ialah isu "kabinet baru" yang akan disusun oleh presiden dan wakil presiden terpilih dalam Pemilu 2019 dan isu korupsi yang dilakukan anggota DPR. Posisi semua metafora tersebut berada pada masing-masing struktur anatomi editorial yaitu attention, conviction, dan direction.

Kekuatan retorika metafora pertama terletak pada makna yang dibangun dari makna domain sumber kepada domain sasaran. Domain sumber metafora yang digunakan untuk isu kabinet baru ialah kendaran yaitu "tancap gas" dan "ban serep". "Tancap gas" digunakan dalam isu kabinet baru yang dimaknai sebagai harapan atau tuntutan kepada kabinet baru agar segera langsung bekerja dan bergerak cepat. "Ban serep" digunakan sebagai peringatan agar Ma'ruf Amin tidak dimanfaatkan hanya sebagai cadangan apabila presiden berhalangan atau tidak bisa melakukan kegiatan. Domain sumber metafora pada isu korupsi bersumber dari kondisi wajah manusia yang memiliki makna citra negatif yaitu "DPR berwajah kusam" dan "bopeng-bopeng". Kata "kusam" dan "bopeng" digunakan untuk membangun makna atribut kepada lembaga DPR bahwa anggota DPR banyak melakukan korupsi. Terdapat juga domain sumber yang lain yaitu kompetisi dengan menggunakan metafora "juara korupsi" dan "coreng DPR". Hal ini menyiratkan makna bahwa DPR telah melakukan kesalahan dalam menjalankan fungsinya sebagai lembaga perwakilan rakyat.

Kekuatan retorika metafora kedua terdapat pada penempatan metafora dalam struktur anatomi editorial yaitu pada attention, conviction, dan direction. Pada anatomi attention metafora digunakan dalam judul dan atau lead (pendahuluan) editorial. Dalam hal ini metafora memiliki dimensi retorika pathos yang diperkirakan akan memancing emosi pembaca agar membaca editorial sampai selesai. Demikian juga dalam anatomi conviction dan direction. Metafora telah memperkuat argumentasi dan pengarahan (logos) yang diperkirakan akan meyakinkan pemikiran pembacanya.

Kekuatan kedua retorika metafora tersebut menjadi satu kekuatan yang lebih besar sebagai reorika ganda (doble rhetoric) metafora dalam editorial media massa dalam menyampaikan opini atau menyatakan sikap media tersebut terhadap isu yang berkembang dalam pemberitaan.

Kekuatan retorika metafora editorial tersebut masih dalam batas analisis teks dengan buktibukti analogi makna domain sumber pada domain sasaran. Pengaruh penggunaan metafora tersebut hanya sebuah perkiraan. Untuk itu, direkomedasikan kepada peneliti lain untuk melakukan penelitian lanjutan tentang pengaruh penggunaan metafora pada pikiran dan sikap pembacanya. Pada tahap penelusuran penggunaan metafora dalam editorial, ternyata tidak semua editorial media massa selalu menggunakan metafora. Disarankan pada redaksi media massa agar menggunakan 
metafora dalam editorialnya dan dalam jumlah lebih banyak lagi karena masyarakat Indonesia umumnya termasuk masyarakat dengan kategori "high context culture". Dengan menggunakan metafora, media massa bisa memuat kritik lebih banyak tanpa menyinggung perasan publik atau mengakibatkan reaksi negatif dari masyarakat.

\section{Ucapan Terima Kasih}

Tim peneliti mengucapkan terima kasih pada Pimpinan Institut Ilmu Sosial dan Ilmu Politik Jakarta yang telah mendukung penelitian ini baik secara moril maupun materil.

\section{DAFTAR PUSTAKA}

Ansary, H., \& Babaii, E. (2005). The generic integrity of newspaper editorials: A systemic functional perspective. RELC Journal, 36(3), 271-295. https://doi.org/10.1177/0033688205060051

Charteris-Black, J. (2004). Corpus Approaches to CriticalMetaphor Analysis. Palgrave Mcmilian.

Cisneros, J. D. (2008). Contaminated Communities: The Metaphor of "Immigrant as Pollutant" in Media Representations of Immigration. Rhetoric \& Public Affairs, 11(4), 569-601. https://doi.org/10.1353/rap.0.0068

Fahnestock, J. (2012). Rhetorical Style. The User of Languagein Persuasion. Oxford : Oxfor University Press.

Fallah, N., \& Raouf Moini, M. (2016). A critical metaphor analysis of Arab uprisings in "The Washington Post" and "Keyhan" editorials. Metaphor and the Social World, 6(1), 79-102. https://doi.org/10.1075/msw.6.1.04fal

Griffin, E. (2015). A First Look at Communication theory (8th Editio). Mc Graw Hill.

Guba, Egon G and Lincoln, Y. S. (2005). Contradiction, and Emerging Conluences. In Y. s Denzin, Norman and Lincoln (Ed.), The Handbook of Qualitative Research (3rd editio). Sage Publication.

Kato-Yoshioka, A. (2016). Differences in structural tendencies between Japanese newspaper editorials and front-page columns: Focus on the location of the main topic. Discourse Studies, 18(6), 676-694. https://doi.org/10.1177/1461445616667181

Kövecses, Z. (2010). Recent developments in metaphor theory Are the new views rival ones? In M. S. P. C. L. P. H. Francisco Gonzálvez-García (Ed.), Metaphor and Metonymy revisited beyond the Contemporary Theory of Metaphor Recent developments and applications. John Benjamins Publishing Company.

Lakoff, George and Johnson, M. (1980). Metaphors We Live By. The University of Chicago Press.

Lakoff, G. (2008). The Neural theory of metaphor. In J. Raymond W. Gibbs (Ed.), The Cambridge Handbook of Metaphor and Thought. Cambridge University Press.

Littlejohn, S. W., Foss, K. A., \& Oetzel, J. G. (1917). Theories of Human Communication (Eleventh E). Waveland Press,INC.

Liu, F. (2018). Lexical metaphor as affiliative bond in newspaper editorials: a systemic functional linguistics perspective. Functional Linguistics, 5(1). https://doi.org/10.1186/s40554-018-0054-z

Lule, J. (2004). War and its metaphors: News language and the prelude to war in Iraq, 2003. Journalism Studies, 5(2), 179-190. https://doi.org/10.1080/1461670042000211168

Magaña, D., \& Matlock, T. (2018). How Spanish speakers use metaphor to describe their experiences with cancer. Discourse and Communication, 12(6), 627-644. https://doi.org/10.1177/1750481318771446

McQuail, D. (2010). McQuail's Mass Communication Theory (6th editio). SAGE Publications Ltd.

Media Indonesia. (2020). https://mediaindonesia.com/statics/tentang-kami

Moleong, L. J. (2011). Metodologi Penelitian Kualitatif. PT Remaja Rosdakarya.

Patton, M. Q. (2002). Qualitative Research and Evaluation Methods (3rd. editi). Sage Publications.

Refaie, E. El. (2001). Metaphors we discriminate by : Naturalized themes in Austrian newspaper articles about asylum seekers 1. 1980, 352-371.

Sahlane, A. (2013). Metaphor as rhetoric: Newspaper Op/Ed debate of the prelude to the 2003 Iraq War. Critical Discourse Studies, 10(2), 154-171. https://doi.org/10.1080/17405904.2012.736397

Steen, G. J. (2010). The contemporary theory of metaphor - now new and improved? In M. S. P. C. L. P. H. Francisco Gonzálvez-García (Ed.), Metaphor and Metonymy revisited beyond the Contemporary Theory of Metaphor Recent developments and applications. John Benjamins Publishing Company. 
Steuter, E., \& Wills, D. (2008). At war with metaphor. In Nueva York: Rowman and .... https://doi.org/10.1186/1471-2148-10-4

Sumadiria, A. S. H. (2004). Menulis Artikel dan Tajuk Rencana: Panduan Praktis Penulis dan Jurnalis Profesional. Simbiosa Rekatama Medua.

Van Dijk, T. A. (1980). Macrostructures: An Interdisciplinary Study of Global Structures in Discourse, Interaction, and Cognition.

Wolseley, R. E. (1969). Understanding Magazines. The IOWA State Universities Press.

Zarza, S., \& Tan, H. (2016). Patterns of schematic structure and strategic features in newspaper editorials: A comparative study of American and Malaysian editorials. Discourse and Communication, 10(6), 635657. https://doi.org/10.1177/1750481316674754 